\title{
THE INFLUENCE OF LEADERSHIP STYLE AND MOTIVATION ON EMPLOYEE PERFORMANCE
}

\author{
Rigan Ahmad Sabastian \\ Universitas Langlangbuana, Indonesia \\ bastianrigan@gmail.com
}

\begin{abstract}
Human resources are the main element that quality must be maintained in a company, good human resources are assessed based on the results of the performance of its employees. Leadership style and motivation are part of the factors that can affect the level of employee performance. This study aims to determine how much influence of leadership style and motivation on employee performance in the management services division of PT. Adyawinsa telecommunication \& electrical Bandung either partially or simultaneously. This research is a descriptive quantitative method using primary and secondary data sources in the form of a questionnaire with 25 employees as respondents. The type of analysis used is path analysis, and to perform data processing, the author uses the help of the SPSS version 23 program. not good, and also the employee's performance is in a bad category. And then the results of this study indicate that partially and simultaneously leadership style has a direct effect on employee performance, then motivation has a direct effect on employee performance and leadership style and motivation affect employee performance.
\end{abstract}

Keywords: Employee performance; Leadership Style; Motivation

\section{INTRODUCTION}

Nowadays technology is achieving a very fast development. However, from the rapid development of technology, the most important thing is that it must be followed by human resources who have high competence and excellence. Given the intense competition, human resources or employees are required to work to be more efficient, effective, and achieve the specified work targets. However, in practice, employee performance experiences ups and downs where at certain times the employee can meet the target, but at other times it can also be below the specified target. This of course cannot be separated from the psychology of the employees in a company. Psychology is of course influenced by various factors or causes that can affect the level of achievement of employee performance.

Performance is the desired result of behavior in carrying out a job. According to Mangkunegara (2016) Performance is the result of work in quality and quantity achieved by an employee in carrying out his duties following the responsibilities assigned to him. Performance is a reflection of their abilities and skills in certain jobs which will have an impact on the rewards of the company. Employee performance cannot be maximized without supporting factors, one of the factors that can support and influence employee performance to be better is the leadership style factor.

According to Hasibuan (2016) leadership style is a way for a leader to influence the behavior of subordinates, so that they are willing to work together and work productively to achieve organizational goals. A leader through the application of his leadership style has a huge influence on the company he leads and every policy issued will affect the quality of work produced by his employees. The leadership style has a very important role in influencing the way employees to work, the appearance of the leadership style will have a positive or negative impact on the performance of the employees they lead. Meanwhile, according to Afandi (2018) Leadership style is an important dynamic force that motivates and coordinates the organization to achieve goals. Leadership style is a method used by leaders in interacting with their subordinates, 
based on research from Pratama (2016) using Structural Equation Modeling techniques which state that Leadership Style has a positive and significant direct effect on employee performance at Bappeda Morowali Regency.

Apart from the leadership style factor, other factors can affect the quality and quantity of employee performance, namely the motivation factor that can encourage employees to produce better performance. Therefore, work motivation can be interpreted as a potential strength that exists within a human being, which he can develop on his own or be developed by several outside forces which essentially revolve around monetary rewards and non-monetary rewards, which can affect his performance results positively or negatively (Winardi, 2016).

Work motivation will greatly affect employee performance, if an employee who works in a company every day and has good work motivation will certainly have a positive impact on employee loyalty and productivity, and of course, the employee will have a good performance too. According to what was stated to Ernest J. McCormick in the journal Rahsel (2016) Motivation is a condition that influences to generate, direct and maintain behavior related to the work environment.

Based on the results of research by Hartono (2018) entitled The Effect of Leadership Style and Work Motivation on Development Performance, it shows that Leadership Style and Work Motivation have a significant effect on development in Besuki Village. As for other research, Dalimunthe (2018) entitled The Effect of Leadership Style and Work Motivation on Employee Performance explains that leadership style and work motivation affect employee performance in the salt consumption business of CV. Pertiwi's work is positive and significant. One of the steps to maintain or improve employee performance can be done by evaluating employee work and making a series of improvements to be able to improve the quality of the employee's work so that the company can grow and excel in competition, or at least remain stable.

Based on the above phenomena, similar to what was experienced by the Manage Services Division of PT Adyawinsa Telecommunication \& Electrical Regional Bandung, this company is engaged in the engineering installation, construction, and maintenance of telecommunication towers. This company was chosen to be one of the partners that have a direct partnership with PT Telekomunikasi Seluler. Where this company has the responsibility to carry out maintenance, repair, and backup power if the condition of the electricity in the towers of PT Telekomunikasi Seluler is cut off. As time goes by, the level of performance achievement at this company in the last one year period has not been so good, this can be seen from the results of achieving employee targets that have not been achieved and also the results of reports given always exceed the predetermined time limit. Therefore, the purpose of this study was to determine how much influence leadership style and motivation on employee performance in the management services division of PT. Adyawinsa telecommunication \& electrical Bandung.

Based on the factors above that have an influence on Leadership Style and Motivation on Employee Performance in the Manage Services Division of PT Adyawinsa Telecommunication \& Electrical, the hypothesis proposed by the researcher is as follows: (1) The leadership style applied to the Managed Services Division of PT. Adyawinsa Telecommunication \& Electrical is not good, (2) Motivation of work carried out at the Manage Services Division of PT. Adyawinsa Telecommunication \& Electrical is not good, (3) Employee performance in the Manage Services Division of PT. Adyawinsa Telecommunication \& Electrical is not good, (4) Leadership style has a big influence on employee performance in the Manage Services Division of PT. Adyawinsa Telecommunication \& Electrical, (5) Work motivation has a big influence on employee performance in the Manage Services Division of PT. Adyawinsa Telecommunication \& Electrical, (6) Leadership style and work motivation have a major effect on employee 
performance in the Manage Services Division of PT. Adyawinsa Telecommunication \& Electrical.

\section{METHODS}

The method used in this research is quantitative research methods. In quantitative research, data analysis is an activity carried out after data from all respondents or other data sources have been collected. And in this research, the type of data used is descriptive data. Data analysis techniques, among others, use Statistical Test with path analysis, Hypothesis Test

In this study, the research location was PT. Adyawinsa Telecommunication \& Electrical Regional Bandung. In this study, researchers used all members of the population totaling 25 people. The reason for using this technique is because the population is relatively small, which is less than 100 people. Primary data in this study were obtained by conducting interviews and distributing questionnaires to employees as respondents in the Manage Services Division of PT. Adyawinsa Telecommunication \& Electrical.

\section{Descriptive Research Results}

\section{RESULTS AND DISCUSSION}

From the descriptive research results obtained from the answers given by respondents by using the questionnaire method to employees of the Manage Services division of PT Adyawinsa Telecommunication \& Electrical Bandung, which aims to find out from each respondent's answer to the items in the questionnaire. Each variable is arranged in the form of a statement with five answer choices given, namely Strongly agree, agree, quite agree, disagree, and strongly disagree from the questionnaire that has been distributed. Based on the results of the questionnaire, the percentage score will be classified based on the respondents' responses as in the table below:

Table 1. Classification of Score Percentage

\begin{tabular}{cc}
\hline Scale & Category \\
\hline $20 \%-35 \%$ & Strongly Disagree \\
$36 \%-51 \%$ & Disagree \\
$52 \%-67 \%$ & Quite Agree \\
$68 \%-83 \%$ & Agree \\
$84 \%-100 \%$ & Strongly agree \\
\hline \multicolumn{2}{c}{ Source: Processed data $(2020)$}
\end{tabular}

From the overall results of the answers given by the respondents regarding the leadership style variable, it can be presented in the recapitulation table as follows: 
Table 2. Recapitulation of Respondents' Answers Regarding Leadership Style

\begin{tabular}{cccccccccc}
\hline $\begin{array}{c}\text { No } \\
\text { Statement }\end{array}$ & SA & A & QA & D & SD & $\begin{array}{c}\text { Number of } \\
\text { Respondents }\end{array}$ & Score & Mean & Category \\
& $\mathbf{5}$ & $\mathbf{4}$ & $\mathbf{3}$ & $\mathbf{2}$ & $\mathbf{1}$ & & & \\
\hline 1 & 5 & 7 & 11 & 1 & 1 & 25 & 89 & 3,56 & Agree \\
2 & 2 & 1 & 3 & 15 & 4 & 25 & 57 & 2,28 & Disagree \\
3 & 2 & 2 & 2 & 13 & 6 & 25 & 56 & 2,24 & Disagree \\
4 & 3 & 2 & 6 & 10 & 4 & 25 & 65 & 2,6 & Disagree \\
5 & 3 & 2 & 3 & 9 & 8 & 25 & 58 & 2,32 & Disagree \\
6 & 4 & 3 & 5 & 7 & 6 & 25 & 67 & 2,68 & Quite Agree \\
7 & 2 & 2 & 4 & 12 & 4 & 25 & 59 & 2,36 & Disagree \\
8 & 1 & 2 & 4 & 10 & 8 & 25 & 53 & 2,12 & Disagree \\
9 & 4 & 4 & 4 & 7 & 6 & 25 & 68 & 2,72 & Quite Agree \\
10 & 1 & 3 & 5 & 9 & 7 & 25 & 57 & 2,28 & Disagree \\
11 & 2 & 3 & 3 & 10 & 7 & 25 & 58 & 2,32 & Disagree \\
12 & 3 & 4 & 5 & 7 & 6 & 25 & 66 & 2,64 & Quite Agree \\
13 & 5 & 6 & 6 & 4 & 4 & 25 & 79 & 3,16 & Quite Agree \\
14 & 5 & 6 & 5 & 5 & 4 & 25 & 78 & 3,12 & Quite Agree \\
15 & 6 & 7 & 7 & 3 & 2 & 25 & 87 & 3,48 & Agree \\
16 & 3 & 2 & 6 & 7 & 7 & 25 & 62 & 2,48 & Disagree \\
17 & 2 & 1 & 2 & 13 & 7 & 25 & 53 & 2,12 & Disagree \\
18 & 2 & 1 & 3 & 12 & 7 & 25 & 54 & 2,16 & Disagree \\
19 & 2 & 2 & 4 & 11 & 6 & 25 & 58 & 2,32 & Disagree \\
20 & 3 & 3 & 4 & 10 & 5 & 25 & 64 & 2,56 & Disagree \\
& & & Total & & & $\mathbf{1 . 2 8 7}$ & $\mathbf{2 , 5 8}$ & Disagree \\
\hline
\end{tabular}

Source: Processed data (2020)

Based on the results from table 2, it can be seen that the total score obtained from the leadership style variable is 1.287 . The results of these scores can then be interpreted as follows:

Maximum Index Value

$=5 \times 20 \times 25=2.500$

Minimum Index Value

$=1 \times 20 \times 25=500$

Interval Distance

$=($ Maximum Value - Minimum Value $): 5$

$=(2.500-500): 5=400$

Score Percentage

$=($ Total Score: Maximum Score $) \times 100 \%$

$=(1.287: 2.500) \times 100 \%=51,48 \%$

Following the results from table 2, it can be seen that the total score obtained regarding the leadership style variable is 1,287 with a percentage score of $51,48 \%$. The results of these scores are in the score interval $900-1.299$ or with a percentage of $36 \%$ - $51 \%$, the value falls into the Disagree category. Based on respondents' answers, it can be stated that the leadership style in the PT Adyawinsa Telecommunication \& Electrical Bandung Service Management division is declared Not good. If based on the hypothesis formulation in point one that has been proposed by stating that the leadership style in 
the Manage Division of this service is not good. According to this statement, it is accepted and acceptable because it is following the results of data processing obtained in the study.

The overall results of the answers given by respondents regarding motivation can be displayed in the recapitulation table as follows:

Table 3. Recapitulation of Respondents' Answers Regarding Motivation

\begin{tabular}{cccccccccc}
\hline No Statement & SA & $\mathbf{A}$ & QA & $\mathbf{D}$ & SD & $\begin{array}{c}\text { Number of } \\
\text { Respondents }\end{array}$ & Score & Mean & Category \\
& $\mathbf{5}$ & $\mathbf{4}$ & $\mathbf{3}$ & $\mathbf{2}$ & $\mathbf{1}$ & & \\
\hline 21 & 4 & 4 & 10 & 4 & 3 & 25 & 77 & 3,08 & Quite Agree \\
22 & 1 & 3 & 8 & 8 & 5 & 25 & 62 & 2,48 & Disagree \\
23 & 2 & 1 & 4 & 12 & 6 & 25 & 56 & 2,24 & Disagree \\
24 & 1 & 2 & 2 & 13 & 7 & 25 & 52 & 2,08 & Disagree \\
25 & 2 & 3 & 2 & 12 & 7 & 25 & 57 & 2,28 & Disagree \\
26 & 7 & 8 & 6 & 2 & 2 & 25 & 91 & 3,64 & Agree \\
27 & 2 & 2 & 5 & 10 & 6 & 25 & 59 & 2,36 & Disagree \\
28 & 1 & 2 & 2 & 12 & 8 & 25 & 51 & 2,04 & Disagree \\
29 & 2 & 1 & 2 & 12 & 9 & 25 & 51 & 2,04 & Disagree \\
30 & 1 & 1 & 3 & 10 & 10 & 25 & 48 & 1,92 & Disagree \\
31 & 1 & 2 & 2 & 9 & 11 & 25 & 48 & 1,92 & Disagree \\
32 & 3 & 5 & 9 & 4 & 4 & 25 & 74 & 2,96 & Quite Agree \\
33 & 2 & 3 & 4 & 8 & 8 & 25 & 58 & 2,32 & Disagree \\
34 & 1 & 3 & 2 & 9 & 10 & 25 & 51 & 2,04 & Disagree \\
35 & 2 & 1 & 2 & 12 & 9 & 25 & 51 & 2,04 & Disagree \\
& & & Total & & & & $\mathbf{8 8 6}$ & $\mathbf{2 , 3 6}$ & Disagree \\
\hline
\end{tabular}

Source: Processed data (2020)

Based on the results of the table above, it can be seen that the total score obtained from the motivation variable is 886 . The result of this score can then be interpreted as follows:

Maximum Index Value

$=5 \times 15 \times 25=1.875$

Minimum Index Value

$=1 \times 15 \times 25=375$

Interval Distance

$=($ Maximum Value - Minimum Value $): 5$

$=(1.875-375): 5=300$

Score Percentage

$=($ Total Score: Maximum Score) x 100\%

$=(886: 1.875) \times 100 \%=47,25 \%$

Following the results of table 3 , it is known that the total score obtained regarding the leadership style variable is 886 with a percentage score of $47,25 \%$. The results of these scores are in the score interval 675 - 974 or with a percentage of $36 \%-51 \%$, the value falls into the Disagree category. Following the respondent's answer, it can be stated that the motivation in the Manage Services division of PT Adyawinsa Telecommunication \& Electrical Bandung is declared Not good. When it is related to the hypothesis formulation in point one that has been proposed, stating that the motivation 
in the management services division of this company is not good. Then the hypothesis can be accepted because it is following the results of data processing obtained in the study.

The overall results of the answers given by respondents regarding employee performance can be displayed in the recapitulation table as follows:

Table 4. Recapitulation of Respondents' Answers Regarding Employee Performance

\begin{tabular}{|c|c|c|c|c|c|c|c|c|c|}
\hline $\begin{array}{c}\text { No } \\
\text { Statement }\end{array}$ & $\begin{array}{c}\text { SA } \\
5\end{array}$ & $\begin{array}{l}A \\
4\end{array}$ & $\begin{array}{c}\text { QA } \\
3\end{array}$ & $\begin{array}{l}\mathrm{D} \\
2\end{array}$ & $\begin{array}{c}\text { SD } \\
1\end{array}$ & $\begin{array}{c}\text { Number of } \\
\text { Respondents }\end{array}$ & Score & Mean & Category \\
\hline 36 & 4 & 4 & 10 & 4 & 3 & 25 & 77 & 3,08 & Quite Agree \\
\hline 37 & 2 & 2 & 7 & 8 & 6 & 25 & 61 & 2,44 & Disagree \\
\hline 38 & 2 & 3 & 4 & 9 & 7 & 25 & 59 & 2,36 & Disagree \\
\hline 39 & 1 & 3 & 3 & 9 & 9 & 25 & 53 & 2,12 & Disagree \\
\hline 40 & 2 & 2 & 4 & 10 & 7 & 25 & 57 & 2,28 & Disagree \\
\hline 41 & 3 & 1 & 4 & 7 & 10 & 25 & 55 & 2,2 & Disagree \\
\hline 42 & 3 & 2 & 3 & 5 & 12 & 25 & 54 & 2,16 & Disagree \\
\hline 43 & 3 & 3 & 3 & 8 & 8 & 25 & 60 & 2,4 & Disagree \\
\hline 44 & 3 & 4 & 4 & 8 & 6 & 25 & 65 & 2,6 & Disagree \\
\hline 45 & 2 & 3 & 8 & 4 & 8 & 25 & 62 & 2,48 & Disagree \\
\hline 46 & 2 & 4 & 5 & 7 & 7 & 25 & 62 & 2,48 & Disagree \\
\hline 47 & 2 & 2 & 5 & 7 & 9 & 25 & 56 & 2,24 & Disagree \\
\hline 48 & 3 & 5 & 10 & 4 & 3 & 25 & 76 & 3,04 & Quite Agree \\
\hline 49 & 2 & 6 & 8 & 6 & 3 & 25 & 73 & 2,92 & Quite Agree \\
\hline 50 & 1 & 3 & 6 & 7 & 8 & 25 & 57 & 2,28 & Disagree \\
\hline 51 & 1 & 2 & 2 & 8 & 12 & 25 & 47 & 1,88 & Disagree \\
\hline \multicolumn{7}{|c|}{ Total } & 974 & 2.435 & Disagree \\
\hline
\end{tabular}

Source: Processed data (2020)

Based on the results of the table above, it can be seen that the total score obtained from the employee performance variable is 974 . The result of this score can then be interpreted as follows:

Maximum Index Value

$=5 \times 16 \times 25=2.000$

Minimum Index Value

$=1 \times 16 \times 25=400$

Interval Distance

$=($ Maximum Value - Minimum Value $): 5$

$=(2.000-400): 5=320$

Score percentage

$=($ Total Score: Maximum Score $) \times 100 \%$

$=(974: 2.000) \times 100 \%=48,70 \%$

Following the results from table 4 above, it is known that the total score obtained regarding the employee performance variable is 974 with a score percentage of $48,70 \%$ and these results are in the score interval 720 - 1.039 with a percentage level of $36 \%$ 51 . This value is included in the score. category disagree. If it is related to the hypothesis in the third point, namely the performance of employees in the management services division of PT Adyawinsa Telecommunication \& Electrical Bandung is not good, then the 
proposed hypothesis can be accepted because it is following the results obtained from the questionnaire data processing in the study.

\section{Verificative Research Results}

This test aims to prove and find the influence of the variable analysis of leadership style and motivation on employee performance in the management service division of PT Adyawinsa Telecommunication \& Electrical Bandung by using path analysis or also known as the path analysis method. In this study, the data obtained using the Likert scale is still ordinal, so that to complete the research needs the data must be transformed first using the Method of Successive Interval (MSI) with additional assistance from stat software in Microsoft Excel 2016 and for complete results can be seen in the appendix. research data.

Based on the proposed hypothesis, the data will then be tested using path analysis to calculate the direct or indirect effect of the independent or dependent variables. And the first step taken is to calculate the correlation coefficient first and then accompanied by calculating the path coefficient as below:

Table 5. Correlation Between Variables

\begin{tabular}{llrrr}
\hline & \multicolumn{2}{c}{$\begin{array}{c}\text { Correlations } \\
\text { Leadership } \\
\text { Style }\end{array}$} & $\begin{array}{c}\text { Motivatio } \\
\mathrm{n}\end{array}$ & $\begin{array}{c}\text { Employee } \\
\text { performance }\end{array}$ \\
\hline Leadership Style & Pearson Correlation & 1 & $.721^{* *}$ & $.875^{* *}$ \\
& Sig. (2-tailed) & & .000 & .000 \\
Motivation & $\mathrm{N}$ & 25 & 25 & 25 \\
& Pearson Correlation & $.721^{* *}$ & 1 & $.858^{* *}$ \\
& Sig. (2-tailed) & .000 & & .000 \\
Employee & $\mathrm{N}$ & 25 & 25 & 25 \\
performance & Pearson Correlation & $.875^{* *}$ & $.858^{* *}$ & 1 \\
\multirow{2}{*}{ **. Correlation is significant at the 0.01 level (2-tailed). } & .000 & .000 & \\
\hline
\end{tabular}

Source: Processed data (2020)

Based on the results of data processing from SPSS software version 23 which is shown in table 5, it can be explained that: (1) The value of the relationship between the variable leadership style $\left(X_{1}\right)$ and the motivation variable $\left(X_{2}\right)$ is 0.721 . So based on the value in the correlation coefficient interpretation guidelines, this value is in the category of a strong relationship level, (2) The value of the relationship between the leadership style variable $\left(\mathrm{X}_{1}\right)$ and the employee performance variable $(\mathrm{Y})$ is 0.875 . then based on the value in the correlation coefficient interpretation guidelines, this value is in the category of a very strong level of relationship, (3) The value of the relationship between the motivation variable $\left(\mathrm{X}_{2}\right)$ and the employee performance variable $(\mathrm{Y})$ is 0.858 . then based on the value in the correlation coefficient interpretation guidelines, this value is in the category of a very strong relationship level.

After getting the correlation coefficient value between the variables $X_{1}, X_{2}$ and $Y$, the next step is to find the path coefficient value of the exogenous variables against endogenous variables using the help of SPSS version 23 software which is presented in the following table: 


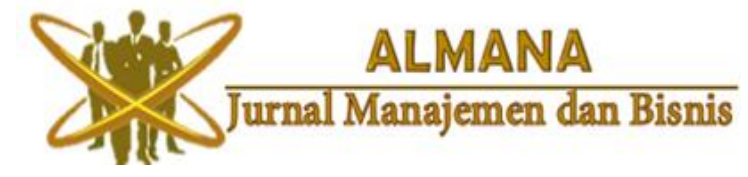

Table 6. Path Coefficient of Exogenous Variables Against Endogenous Variables

\begin{tabular}{|c|c|c|c|c|c|c|}
\hline \multirow{2}{*}{\multicolumn{2}{|c|}{ Model }} & \multicolumn{3}{|c|}{ Coefficients $^{\mathrm{a}}$} & \multirow{2}{*}{$\mathrm{t}$} & \multirow{2}{*}{ Sig. } \\
\hline & & - & Std. Error & $\begin{array}{c}\text { Coefficients } \\
\text { Beta }\end{array}$ & & \\
\hline & (Constant) & -3.696 & 3.530 & & -1.047 & .306 \\
\hline & Leadership Style & .442 & .087 & .538 & 5.049 & .000 \\
\hline & Motivation & .561 & .126 & .473 & 4.442 & .000 \\
\hline & pendent V & loyee perforn & & & & \\
\hline
\end{tabular}

Source: Processed data (2020)

Based on the results in the table above, it is known that the value of Standardized Coefficients Beta in each variable is 0.538 and 0.473 which shows the path coefficient value of leadership style (PYX1 $=0.538$ and motivation $(P Y X 2=0.473$ ) on employee performance.

Based on the results of data processing using SPSS version 23 software, the coefficient of determination of the exogenous variables $\left(X_{1}\right.$ and $\left.X_{2}\right)$ on endogenous variables $(Y)$ and the influence of other variables is obtained through the table below:

Table 7. The coefficient of determination ( $R$ square)

\begin{tabular}{lcccc}
\hline Model & $\mathrm{R}$ & \multicolumn{2}{c}{ Model Summary } & \\
$\mathrm{R}$ Square & Adjusted R & \multicolumn{2}{c}{$\begin{array}{c}\text { Std. Error of the } \\
\text { Estimate }\end{array}$} \\
\hline 1 & $.938^{\mathrm{a}}$ & .880 & .869 & 5.426 \\
a. Predictors: (Constant), X2, X1 & & & \\
\hline
\end{tabular}

Source: Processed data (2020)

Based on the results from table 7 , the coefficient value ( $R$ square) can be interpreted as the magnitude of the influence value of the variable leadership style $\left(X_{1}\right)$ and motivation $\left(\mathrm{X}_{2}\right)$ on the employee performance variable $(\mathrm{Y})$ which has an effect of 0.880 or $88 \%$. Meanwhile, there is a remaining value of $12 \%$ which is the influence of other variables outside of the research.

\section{Hypothesis test}

Partial Hypothesis Testing (t-test)

The t-test or partial testing is carried out to prove whether the variable leadership style $\left(X_{1}\right)$ and motivation $\left(X_{2}\right)$ influences the employee performance variable $(Y)$ in the management services division of PT Adyawinsa telecommunication \& electrical Bandung. Furthermore, in this study, the significance test with path analysis is to compare the $t$-count value with the t-table value with a significance level of 0.05 or $5 \%$ using SPSS version 23 software which can then obtain the following results:

Table 8. Hypothesis Testing Results Partially

\begin{tabular}{|c|c|c|c|c|c|c|}
\hline \multirow{2}{*}{\multicolumn{2}{|c|}{ Model }} & \multicolumn{2}{|c|}{ Coefficients $^{\mathbf{a}}$} & \multirow{2}{*}{$\begin{array}{c}\text { Standardized } \\
\text { Coefficients } \\
\text { Beta }\end{array}$} & \multirow[t]{2}{*}{$\mathrm{t}$} & \multirow[t]{2}{*}{ Sig. } \\
\hline & & $B$ & Std. Error & & & \\
\hline & (Constant) & -3.696 & 3.530 & & -1.047 & .306 \\
\hline & ip Style & .442 & .087 & .538 & 5.049 & .000 \\
\hline & Motivation & .561 & .126 & .473 & 4.442 & .000 \\
\hline & Dependent Varia & loyee perform & & & & \\
\hline
\end{tabular}

Source: Processed data (2020) 
In this study, the significant level used is $(\alpha): 0.05$ or $5 \%, d f=(n-k-1)=25-2-1=$ 22 , then for the two-sided test, the t-table value is 2.074 . Judging from table 8 , it is obtained that the $t$ value of the leadership style variable is $5.049 \geq t$ table 2.074 with a significant value of 0.000 smaller than $\alpha=0.05$. then $\mathrm{H} 0$ is rejected and $\mathrm{H} 1$ is accepted, which means that partially the leadership style variable affects the performance of employees in the management services division of PT Adyawinsa telecommunication \& electrical Bandung.

Table 8 also shows that the leadership style variable has a significant effect on the performance of employees in the management services division of PT Adyawinsa telecommunication \& electrical Bandung, which means that the variable leadership style is one of the factors that have a significant role in improving employee performance.

Based on the provisions of the criteria above, it can be seen that when viewed from table 8 , the $t$ count value of the leadership style variable is $4,442 \geq t$ table 2,074 with a significant value of 0.000 smaller than $\alpha=0.05$. then $\mathrm{H} 0$ is rejected and $\mathrm{H} 1$ is accepted, which means that partially the motivation variable affects the performance of employees in the management services division of PT Adyawinsa telecommunication \& electrical Bandung. Also, the motivation variable has a significant effect on the performance of employees in the management services division of PT Adyawinsa telecommunication \& electrical Bandung, which means that the motivation variable is one of the factors that have an important role in improving employee performance.

To prove the simultaneous influence of leadership style and motivation variables on employee performance in the management services division of PT Adyawinsa telecommunication \& electrical Bandung, hypothesis testing was carried out using SPSS version 23 software, the $\mathrm{F}$ test can be seen in the following table:

Table 9. Simultaneous Hypothesis Testing Results

\begin{tabular}{|c|c|c|c|c|c|c|}
\hline \multirow{2}{*}{\multicolumn{2}{|c|}{ Model }} & \multicolumn{3}{|c|}{ ANOVA $^{a}$} & \multirow[b]{2}{*}{$\mathrm{F}$} & \multirow[b]{2}{*}{ Sig. } \\
\hline & & $\begin{array}{c}\text { Sum of } \\
\text { Squares }\end{array}$ & & Mean Square & & \\
\hline 1 & $\begin{array}{l}\text { Regression } \\
\text { Residual }\end{array}$ & $\begin{array}{r}4751.148 \\
647.812\end{array}$ & $\begin{array}{r}2 \\
22\end{array}$ & $\begin{array}{r}2375.574 \\
29.446\end{array}$ & 80.676 & $.000^{\mathrm{b}}$ \\
\hline $\begin{array}{l}\text { a. De } \\
\text { b. } P r\end{array}$ & $\begin{array}{l}\text { dent Varic } \\
\text { tors: (Con }\end{array}$ & $\begin{array}{l}\text { nployee perfo } \\
\text { Motivation, Le }\end{array}$ & ip & & & \\
\hline
\end{tabular}

Source: Processed data (2020)

Based on the results from table 9, it can be seen that the $F$ count value is 80,676 with a significant value of 0.000 . then $\alpha=0.05$, df_1 $=2$ and df_L $=(n-k-1)=(25-2-1)=$ 22 then the value of $F$ table $=3.44$ is obtained. Because $F$ hitung $>F$ table (80.676> 3.44) then $\mathrm{HO}$ is rejected and $\mathrm{H} 1$ is accepted, which means that simultaneously the leadership style and motivation variables affect the performance of employees in the management services division of PT Adyawinsa telecommunication \& electrical Bandung.

Based on the simultaneous hypothesis testing, it shows that the variables of leadership style and motivation affect the performance of employees in the management services division of PT Adyawinsa telecommunication \& electrical Bandung. This statement is following the image above which shows $F_{\text {count }}$ is in the rejection area $\mathrm{HO}$. In other words, the variables of leadership style and motivation are factors that have an important role in improving employee performance.

Employee performance in a company is influenced by many factors including leadership style and motivation, good employee performance affects company development. Based on the test results in this study, simultaneously it shows that the 
results of testing the correlation coefficient variables of leadership style and motivation have a strong effect on employee performance. So it can be interpreted that the better the leadership style that is applied and the motivation is given, the better the resulting employee performance process.

The results of the above statement can be strengthened by the research journal Hartono (2018), based on the results of this study it is concluded that there is an influence between leadership style and motivation on employee performance. The results above are following the factors that can affect employee performance as stated by Kashmir (2016) including (1) Ability and expertise, (2) Knowledge, (3) Work design, (4) Personality, (5) Work motivation, (6) leadership style, (7) and others.

\section{CONCLUSION}

The leadership style applied to the management services division of PT Adyawinsa telecommunication \& electrical Bandung is in a bad category. One of the factors is that employees feel that their leadership has not been able to establish good emotional relationships with their subordinates. So it can be concluded that the leadership style applied to the company is categorized as bad. Meanwhile, the motivation given to employees in the management services division of PT Adyawinsa telecommunication \& electrical Bandung is in a bad category either. One of the factors is that employees as respondents feel there is no appreciation if employees can complete work achievement targets before the specified time.

The performance of employees in the management services division of PT Adyawinsa telecommunication \& electrical Bandung is in a bad category. One of the factors is that employees feel unable to complete work targets before the specified deadline, of course, this factor arises from the problems of the two variables above, namely regarding the leadership style applied and the motivation given.

\section{REFERENCES}

Afandi. P. (2018). Manajemen Sumber Daya Manusia (teori, konsep dan Indikator). Yogyakarta: Zanafa Publishing.

Dalimunthe, H. (2018). Pengaruh Gaya Kepemimpinan dan Motivasi Kerja Terhadap Kinerja Karyawan Usaha Pembungkusan Garam. Jurnal Konsep Bisnis dan Manajemen. 5(1), 54-62.

Hartono, B. (2018). Pengaruh Gaya Kepemimpinan dan Motivasi Kerja Terhadap Kinerja Pembangunan. Jurnal Politico, 18(1), 41-53.

Hasibuan. S.P. (2016). Manajemen Sumber Daya Manusia Edisi Revisi. Jakarta: PT Bumi Aksara.

Kashmir. (2016). Manajemen Sumber Daya Manusia Cetakan Kesatu. Jakarta: PT Rajagrafindo Persada.

Mangkunegara. A.P. (2016). Manajemen Sumber Daya Manusia Perusahaan. Bandung: PT Remaja Rosdakarya.

Pratama, T. (2016). Pengaruh Gaya Kepemimpinan terhadap Kinerja Pegawai pada Badan Perencanaan, Penelitian dan Pembangunan Daerah (Bappeda) Kabupaten Morowali Dengan Motivasi Kerja sebagai Variabel Intervening. e Jurnal Katalogis, 4(8), 54-61.

Rahsel, Y. (2016). Pengaruh Motivasi Kerja terhadap Kinerja Pegawai Administrasi Pusat Universitas Padjajaran Bandung (Studi pada Bagian Administrasi Umum UNPAD). Jurnal Manajemen Magister, 2(2), 208-220.

Winardi. (2016). Kepemimpinan Dalam Manajemen. Jakarta: PT. Rineka Cipta. 